Stepanov G. F., Tereshchenko L. O., Oleinik E. V., Maryniuk G. S., Budalenko O. I., Dubna E. S. Efficiency of ademethionine in oxidative stress in tissues of irradiated rats. Journal of Education, Health and Sport. 2021;11(06): 192-198. eISSN 2391-8306. DOI http://dx.doi.org/10.12775/JEHS.2021.11.06.021

https://apcz.umk.pl/czasopisma/index.php/JEHS/article/view/JEHS.2021.11.06.021

https://zenodo.org/record/5083217

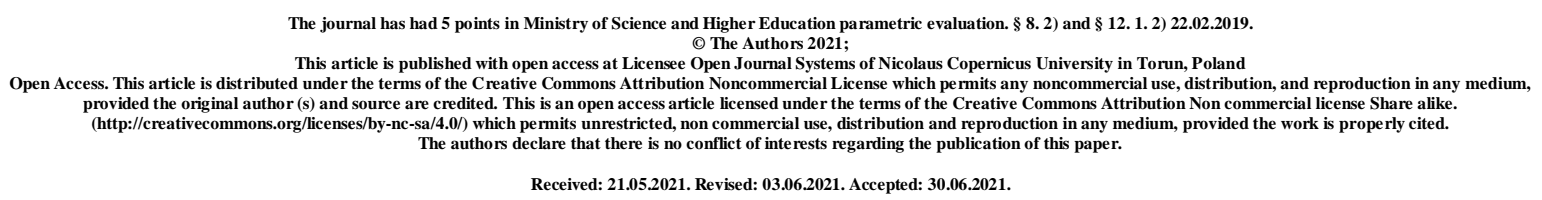

UDK 612-092.9: 612.014.482.4: 577.152.193: 547.441: 615.244

\title{
EFFICIENCY OF ADEMETHIONINE IN OXIDATIVE STRESS IN TISSUES OF IRRADIATED RATS
}

\author{
G. F. Stepanov, L. O. Tereshchenko, E. V. Oleinik, G. S. Maryniuk, O. I. Budalenko, \\ E. S. Dubna
}

\section{Odessa National Medical University, Odessa, Ukraine}

Abstract

Introduction. Ionizing radiation in low doses of low intensity causes prolonged activationof lipid per oxidation and depletion of the antioxidant system in a living organism. Moreover, Ademethionine is currently being considered as a promisingantioxidant.

Method. Experimental studies were carried out on 60 sexually mature male Wistar rats. The animals were irradiated in a total dose of $1 \mathrm{~Gy}$ on a $\gamma$-therapeutic device AGAT-R No. 83 (isotope ${ }^{60} \mathrm{Co}$ ). At the end of the total dose, the rats were injected intraperitoneally with Heptral (ademethionine) after 15 minutes, 12, 24, 36, 48, 60, 72, 84, 96, 108, 120, 132, 144,156 hours after radiation exposure at the rate of $10 \mathrm{mg} / \mathrm{kg}$ mass. After the introduction of Heptral, the animals were taken into the experiment after 24 hours, 3, 7, 15 days. In homogenates of the spleen and thymus of animals, the amount of oxidized and reduced forms of pyridine nucleotides was determined.

Results. Chronic $\gamma$-irradiation in a total dose of $1 \mathrm{~Gy}$ leads to a significant decrease in the content of reduced forms of pyridine nucleotides in the spleen and thymus of rats. Administration of Heptral to irradiated animals normalized oxidative homeostasis. So, on the 
7th day of the experiment, the amount of oxidized forms of pyridine nucleotides in the spleen was $47.3 \%$ lower, and reduced - $36.3 \%$ higher than in animals that did not receive treatment. At the end of the observation period, the reduction coefficient of pyridine nucleotides in the spleen slightly differed from the control level. In comparison with irradiated animals, which were not injected with Heptral, the NADP content was lower by $70.3 \%$, and $\mathrm{NADPH}_{2}-$ higher by $48.8 \%$.

Conclusion. The course administration of Heptral to irradiated animals leads to the normalization of the reduction factor of pyridine nucleotides. According to its mechanism of action, Heptral can be used in the complex treatment of low- intensity radiation injuries in low doses.

Key words: $\gamma$-irradiation; spleen; thymus; pyridine nucleotides; ademethionine.

\section{Introduction}

The effect of ionizing radiation on a living organism is characterized by prolonged activation of the processes of lipid peroxidation (LPO) and depletion of the physiological antioxidant system (AOS). $\gamma$-irradiation leads to the accumulation of LPO products in many organs, primarily radiosensitive. These include organs involved in the immune response and hematopoiesis (spleen, thymus, bone marrow) [1].

Global technogenic pollution of the environment, in particular with radionuclide's, makes it urgent to search for pharmacological drugs that can effectively correct the pronounced imbalance in the LPO -AOS system of the body, arising against the background of chronic exposure to low doses of $\gamma$-radiation [2].

Heptral (ademethionine), which is a precursor of cysteine, taurine, and glutathione, is currently considered as a promising antioxidant $[3,4,5]$. To date, the most studied area of therapeutic use of ademethionine is liver disease and depression, since it has a unique combination of hepatoprotective, antioxidant and antidepressant properties $[6,7,8]$.

The aim of this work is to study the possibility of using Heptral in the case of disturbances in the functioning of the glutathione AOS unit in the spleen and thymus of rats exposed to chronic low-intensity $\gamma$-irradiation at low doses.

\section{Method}

Experimental studies were carried out on 60 sexually mature male Wistar rats. The animals were irradiated in a total dose of 1 Gy on a $\gamma$-therapeutic device AGAT-R No. 83 ( ${ }^{60}$ Co isotope). Specifications: $0.1 \mathrm{~Gy}$ every 24 hours, dose rate $0.39 \mathrm{~g} / \mathrm{h}$; source-field distance $100 \mathrm{~cm}$; exposure $2.64 \mathrm{~min}$. At the end of the total dose of irradiation, the first group of 
animals was injected intraperitoneally with saline, then they were taken into the experiment after 24 hours, 3, 7, 15 days, rats from the other group were injected with Heptral intraperitoneally after 15 minutes, 12, 24, 36, 48, 60, 72, 84, 96, 108, 120, 132, 144 ,156 hours after radiation exposure at the rate of $10 \mathrm{mg} / \mathrm{kg}$ mass.

At the end of the introduction of Heptral, the animals were taken into the experiment after 24 hours, 3, 7, 15 days. In homogenates of the spleen and thymus of animals, the amount of oxidized and reduced forms of pyridine nucleotides was determined [9].

The data obtained were subject to statistical processing by the method of estimating the average using "T tables" using programs "Primer Biostatistics" and "Excel” [10].

\section{Results}

As evidenced by the results of the study, chronic $\gamma$-irradiation in a total dose of $1 \mathrm{~Gy}$ leads to a significant decrease in the reduced forms of pyridine nucleotides in the spleen and thymus rats.

Table 1

Content of NADP and NADPH in the spleen and thymus rats, which were irradiated at the total dose of $1 \mathrm{~Gy}(\mathrm{M} \pm \mathrm{m}, \mathrm{n}=6, \mathrm{nmol} / \mathrm{g})$

\begin{tabular}{|c|c|c|c|c|c|}
\hline \multirow{3}{*}{\multicolumn{2}{|c|}{$\begin{array}{l}\text { A series of } \\
\text { experiments }\end{array}$}} & \multicolumn{4}{|c|}{ The content of pyridine nucleotides } \\
\hline & & \multicolumn{2}{|c|}{ NADP } & \multicolumn{2}{|c|}{ NADPH } \\
\hline & & spleen & thymus & spleen & thymus \\
\hline \multicolumn{2}{|c|}{ Control } & $135,60 \pm 12,44$ & $90,30 \pm 10,60$ & $495,10 \pm 18,48$ & $140,70 \pm 13,40$ \\
\hline \multirow{5}{*}{ 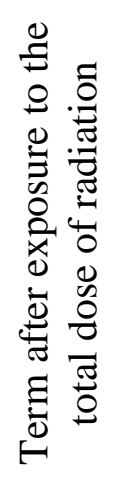 } & $\begin{array}{c}\text { At once } \\
\text { after }\end{array}$ & $163,81 \pm 14,90$ & $114,14 \pm 13,36$ & $397,57 \pm 14,78$ & $108,20 \pm 10,30$ \\
\hline & $\begin{array}{c}24 \\
\text { hours }\end{array}$ & $191,47 \pm 21,00$ & $136,44 \pm 16,00$ & $346,57 \pm 12,94$ & $98,63 \pm 9,39$ \\
\hline & $\begin{array}{c}3 \\
\text { days }\end{array}$ & $207,88 \pm 22,80$ & $160,55 \pm 18,87$ & $330,23 \pm 12,33$ & $84,42 \pm 8,04$ \\
\hline & $\begin{array}{c}7 \\
\text { days } \\
\end{array}$ & $228,76 \pm 21,00$ & $173,47 \pm 20,35$ & $271,81 \pm 10,15$ & $67,68 \pm 6,45$ \\
\hline & $\begin{array}{c}15 \\
\text { days }\end{array}$ & $244,08 \pm 22,40$ & $183,76 \pm 21,62$ & $236,66 \pm 8,83$ & $59,66 \pm 5,68$ \\
\hline
\end{tabular}

Note $\mathrm{P}<0.05$ on a parity basis with the control in the drop

This may be due to several reasons, in particular, the increased use of reduced equivalents in the process of neutralizing reactive oxygen species or, possibly, inhibition of the reactions in which they are formed, primarily glucose-6- phosphate dehydrogenase. It is known that for the course of enzymatic reactions, it is not so much the absolute amount of pyridine nucleotides that is important, but the ratio of the concentration of reduced and oxidized forms [11]. Table 2 shows the values of the reduction coefficient of pyridine 
nucleotides, which indicate profound disturbances in the redox system of the spleen and thymus of irradiated rats.

Table 2

NADPH / NADP ratio in the spleen and thymus of rats irradiated at a total dose of $1 \mathrm{~Gy}$

\begin{tabular}{|c|c|c|c|}
\hline \multirow{2}{*}{ A series of experiments } & \multicolumn{2}{c|}{ NADPH/ NADP ratio } \\
\cline { 2 - 4 } & Spleen & thymus \\
\hline \multicolumn{2}{|c|}{ Control } & 3,65 & 1,56 \\
\hline \multirow{2}{*}{$\begin{array}{c}\text { Term after exposure } \\
\text { to the total dose of } \\
\text { radiation }\end{array}$} & At once after & 2,43 & 0,95 \\
\cline { 2 - 4 } & 24 hours & 1,81 & 0,72 \\
\cline { 2 - 4 } & 3 days & 1,59 & 0,53 \\
\cline { 2 - 4 } & 7 days & 1,19 & 0,39 \\
\cline { 2 - 4 } & 15 days & 0,97 & 0,32 \\
\hline
\end{tabular}

As evidenced by the data shown in Table 3, 24 hours after the completion of the course of Heptral administration to irradiated animals, the NADP content in the spleen was $150 \%$, and $\mathrm{NADPH}_{2}-80.9 \%$ relative to the intact group. But in comparison with animals that did not receive the drug, the amount of NADP is slightly higher, and $\mathrm{NADPH}_{2}$ - significantly exceeds this indicator.

Day 3 of the study is characterized by a decrease in the amount of NADP in comparison with the previous period by $20.5 \%$, while $\mathrm{NADPH}_{2}$ practically does not differ from it. During the study period, in rats that were not injected with Heptral, the concentration of NADP in the spleen was higher by $23.7 \%$, and $\mathrm{NADPH}_{2}-$ decreased by $18.3 \%$.

On the 7 th day, the content of oxidized forms was $47.3 \%$ lower, and of reduced forms - $36.3 \%$ higher than in animals that did not receive treatment.

Such positive trends continued in the future. Thus, at the end of the experiment, the reduction factor of pyridine nucleotides in the spleen slightly differs from the control level. In comparison with irradiated animals, which were not injected with Heptral, the content of $\mathrm{NADP}$ is lower by $70.3 \%$, and $\mathrm{NADPH}_{2}$ is higher by $48.8 \%$.

In the thymus of rats, a similar dynamics of changes in the amount of oxidized and reduced forms of NADP was noted, and by the 15th day after the end of the total dose of irradiation and the course of Heptral administration, the concentration of NADP was $14.2 \%$ higher than the control values, and $\mathrm{NADPH}_{2-}$ was almost at the level of the latter. In comparison with a similar group of animals that did not receive the drug, the amount of NADP decreases by $89.3 \%$, and $\mathrm{NADPH}_{2}$ - increases by $47.6 \%$. 
Table 3

Influence of course administration of Heptral of NADP and NADPH cities in spleen and thymus of rats irradiated in total dose of $1 \mathrm{~Gy}(\mathrm{M} \pm \mathrm{m}, \mathrm{n}=6, \mathrm{nmol} / \mathrm{g})$.

\begin{tabular}{|c|c|c|c|c|c|}
\hline \multirow{3}{*}{\multicolumn{2}{|c|}{$\begin{array}{l}\text { A series of } \\
\text { experiments }\end{array}$}} & \multicolumn{4}{|c|}{ The content of pyridine nucleotides } \\
\hline & & \multicolumn{2}{|c|}{ NADP } & \multicolumn{2}{|c|}{ NADPH } \\
\hline & & spleen & thymus & spleen & thymus \\
\hline \multicolumn{2}{|c|}{ Control } & $135,60 \pm 12,44$ & $90,30 \pm 10,60$ & $495,10 \pm 18,48$ & $140,70 \pm 13,40$ \\
\hline \multirow{4}{*}{ 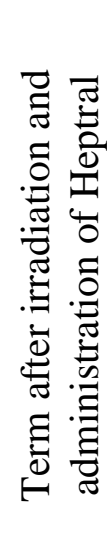 } & $\begin{array}{c}24 \\
\text { hours }\end{array}$ & $203,54 \pm 18,66$ & $139,97 \pm 16,46$ & $400,54 \pm 14,95$ & $105,10 \pm 10,00$ \\
\hline & $\begin{array}{c}3 \\
\text { days }\end{array}$ & $175,74 \pm 16,17$ & $121,72 \pm 14,29$ & $420,84 \pm 15,71$ & $115,52 \pm 11,00$ \\
\hline & $\begin{array}{c}7 \\
\text { days }\end{array}$ & $164,62 \pm 15,05$ & $117,57 \pm 13,78$ & $451,53 \pm 16,85^{*}$ & $119,45 \pm 11,38$ \\
\hline & $\begin{array}{c}15 \\
\text { days }\end{array}$ & $148,75 \pm 13,68^{*}$ & $103,12 \pm 12,08$ & $478,27 \pm 17,85^{*}$ & $126,63 \pm 12,06$ \\
\hline
\end{tabular}

Note*- $\mathrm{P}>0,05$ in relation to the control

Table 4

The effect of course administration of Heptral on the ratio of NADPH /NADP in the spleen and thymus of rats irradiated at a total dose of $1 \mathrm{~Gy}(\mathrm{M} \pm \mathrm{m}, \mathrm{n}=6)$.

\begin{tabular}{|c|c|c|c|}
\hline \multicolumn{2}{|c|}{} & \multicolumn{2}{c|}{ The ratio NADPH/ NADP } \\
\cline { 2 - 4 } A series of experiments & Spleen & Thymus \\
\hline \multicolumn{2}{|c|}{ Control } & $3,65 \pm 0,20$ & $1,56 \pm 0,11$ \\
\hline \multirow{3}{*}{$\begin{array}{c}\text { Term upon completion } \\
\text { of the total dose and } \\
\text { administration of Heptral }\end{array}$} & 24 hours & $1,97 \pm 0,09$ & $0,75 \pm 0,04$ \\
\cline { 2 - 4 } & 3 days & $2,40 \pm 0,14$ & $0,95 \pm 0,06$ \\
\cline { 2 - 4 } & 7 days & $2,74 \pm 0,16$ & $1,02 \pm 0,07$ \\
\hline
\end{tabular}

Note $\mathrm{P}<0.05$ compared to control in all cases

Thus, the studies carried out demonstrate the positive effect of Heptral on the regulation of the relationship between oxidized and reduced forms of NADP in an irradiated organism, thereby contributing to the strengthening of the functional link of the glutathione redox system, which they are part of. 


\section{Conclusion}

1. Chronic $\gamma$-irradiation in a total dose of $1 \mathrm{~Gy}$ leads to a significant violation of the ratio of oxidized and reduced forms of pyridine nucleotides in the thymus and spleen of experimental rats.

2. Course administration of Heptral to irradiated animals leads to the normalization of the reduction factor of pyridine nucleotides.

3. Heptral, by its mechanism of action, can be used in the complex treatmentof lowintensity radiation injuries in low doses.

\section{References}

1. Baraboy V.A., Sutkovoy D.A. Oxidation-antioxidant homeostasis in normal andpanological conditions. Unit of Y. Zozulya. Kiev, Naukova Dumka, 1997. - 202 p.

2. Orumo B.K., Elokhin A.P., Ksenafontov A.I. Features of ionizing radiation effects on biological objects and methods for its radiation monitoring at nuclear facilities. Global Nuclear Safety. - 2020. - № 2 (35). P.16-41.

3. Belenichev I.F., Kucher T.V. The influence of thiol antioxidants on the state of nitrosating stress in brainof rats with chronic ethanol intoxication. Pharmacology and drug toxicology. - 2016. - № 2. P. 24-29.

4. Pogotova G.A., Chekman I.S., Gorchakova N.O. et al. Efficiency of heptral and polyunsaturated fatty acids in condition of oxidative stress in animals. Medichnakhimiya. - 2011. - № 4. P. 164.

5. Aquilano K., Baldelli S., Ciriolo Maria R. Glutathione: new roles in redox signaling for an old antioxidant. Front Pharmacol. - 2014.- № 5. P. 196.

6. Cederbaum A.I. Hepatoprotective effects of S-adenosyl-L-methionine againstalchol-and cytochrom P450 2E1-induced liver injury. World J. Gastroenterol. - 2010. № 11 (16). P. 1366-1376.

7. Turner P., Kantaria R., Young A. A systematic review and meta-analysis of the evidence base for add-on treatment for patients with major depressive disorder who have not responded to antidepressant treatment: A European perspective. J. of Psychopharmacology. - 2014. № 2 (28). P. 85-98.

8. Yuriev K.L. Ademethionine for liver diseases. Evidence dossier // Ukrainian Medical Hourly. - 2011. - №. 3. P. 63-69.

9. Methods of biochemical research / ed. Prokhorova M.N. - L .: publishing house ofthe Leningrad University, 1982. - $272 \mathrm{p}$.

10. Lapach S.N., Chubenko A.V., Babich P.N. Statistical methods in biomedical 
research using Excel. Kyiv, MORION, 2000. - 320 p.

11. Zayarna SP Pathophysiological mechanisms of disorders of redox processes in the blood system of the heirs of irradiated rats: author's ref. Candidate of Dissertation honey. Sciences: 14.03.04 / Odessa State Medical University. - Odessa, 1998. - 18p. 